\title{
Source-Sink Manipulations Differentially Affected Carbon and Nitrogen Dynamics, Fruit Metabolites and Yield of Sacha Inchi Plants
}

Zhiquan Cai ( $\nabla$ zhiquan.cai@126.com )

Chinese Academy of Sciences https://orcid.org/0000-0002-1988-1704

Tao Xie

Foshan University

Jin Xu

Shanxi Agricultural University

\section{Research article}

Keywords: Plukenetia volubilis, source-sink regulations, physiological traits, growth, reproductive trait, fruitlet metabolites

Posted Date: November 10th, 2020

DOI: https://doi.org/10.21203/rs.3.rs-101512/v1

License: () (i) This work is licensed under a Creative Commons Attribution 4.0 International License. Read Full License

Version of Record: A version of this preprint was published at BMC Plant Biology on March 30th, 2021. See the published version at https://doi.org/10.1186/s12870-021-02931-9. 


\section{Abstract}

Background: Being a promising tropical woody oilseed crop, the evergreen and recurrent plants of Sacha Inchi (Plukenetia volubilis L.) has complex phenology and source-sink interactions. Carbon source-sink manipulations with control and two treatments (reduce source, ca. 10\% mature leaf pruning; reduce sink, $10 \%$ fruitlet thinning) were conducted on 2.5-year-old field-grown $P$. volubilis plantation during the early-wet season in a seasonal tropical area.

Results: Leaf photosynthetic rate and specific leaf area largely remained unchanged in response to defoliation or defloration. Compared with control, higher $\mathrm{N}$ contents on average were observed in both remaining leaves and branches of the defoliated plants, suggesting that $\mathrm{N}$-mobilization was mainly due to the enhanced $\mathrm{N}$ uptake from soil. Carbon, but not $\mathrm{N}$, is a source-driven growth process of $P$. volubilis plants, as defoliation reduced the contents of non-structural carbohydrates (especially sugar) in branches, although temporally, whereas defloration increased available $\mathrm{C}$ reserve. The seasonal dynamic pattern of fruit ripening was altered by source-sink regulations. The total seed yield throughout the growing season that depends on fruit set and retention (i.e., number of matured fruit) rather than individual fruit development (size), was slightly increased by defloration but was significantly decreased by defoliation. Compared with control, defloration did not enrich the KEGG pathway, but defoliation downregulated the TCA cycle and carbohydrate and lipid metabolisms in fruitlets after 24 days of the applications of source-sink manipulation.

Conclusion: Carbohydrate reserves served to buffer sink-source imbalances that may result from temporary adjustment in demand for assimilates (e.g., defloration) or shortfalls in carbon assimilation (e.g., defoliation). Defoliation is disadvantageous for the yield and also for carbohydrate and lipid accumulation in fruits of $P$. volubilis plants. Although more studies are needed, these results provide new insights to the further improvement in seed yield of the strong source-limited $P$. volubilis plants by source/sink manipulations.

\section{Background}

Plant growth and reproduction consume large amounts of carbohydrate and nitrogen $(\mathrm{N})$, which are dominantly derived from photosynthate and $\mathrm{N}$ absorption from soils, respectively, and/or the remobilization of internal reserves [1, 2]. Although $\mathrm{C}$ and $\mathrm{N}$ metabolism are strongly interconnected, the storage physiology of both nutrients shows great differences in response to resource-sink regulations [3]. For instance, nonstructural carbohydrates (NSC; mainly sugar and starch), an indicators of a plant's carbon balance, were stored in all tissues of woody plants, and remobilization of $\mathrm{C}$ reserves is controlled by sink strength [4, 5]. In contrast, $\mathrm{N}$ storage tends to be concentrated in specific tissues and $\mathrm{N}$ remobilization is mainly source driven, depending on the stored $\mathrm{N}$ amount $[1,2,6]$.

For crops, by coordinating the relationship between source (e.g., mature leaf) and sink (e.g., fruit) and between the vegetative and reproductive growth, leaf/shoot pruning and mechanically or chemically thinning of flowers and/or fruitlets has been successfully applied to improve fruit load and fruit growth (yield) in some temperate and tropical fruit trees $[7,8,9]$. However, plant physiological response to source-sink manipulations is complex and depends on species/variety, environmental conditions, and timing and severity of pruning $[5,9,10]$. Fruit set and fruit development are at least related to carbohydrate availability; for a certain woody crop, a suitable fruit set and fruit number per plant owing to properly thinning of flowers and/or fruitlets can avoid an excessive fruit load on the plant that may lead to starvation in later stages [11]. But in an exceptional case of the intensively cultivated olive orchards, the $\mathrm{C}$ reserve pools in woody tissues, acting as an active sink, was not affected by high fruit load and fruit development did not significantly tap the tree's $C$ reserve pools [12]. On the other hand, the degree to which plant growth and/or reproduction increased will be a function of both the extent of defoliation and the photosynthetic compensatory employed by tree $[13,14,15]$. At the leaf level, defoliation has been demonstrated to either no change or a decrease in gas exchange, or even enhance the photosynthetic capacity of the remaining leaves in some woody species (e.g., Eucalyptus nitens [16]; Abies balsamea [6]). But the transitory compensatory response in leaves generally disappeared when leaf area was rebuilt [16, 17]. At the whole-plant level, in response to leaf or shoot pruning, perennial plant triggers changes in partitioning and translocation of photosynthate and $\mathrm{N}$. The increased utilization of $\mathrm{C}$ and $\mathrm{N}$ reserves stored in the woody tissues support the production of new leaves, inflorescence induction, and plant development, which is essential for a sustainable crop production in term of internal source:sink balance [5]. Moreover, the fruits (seeds) metabolites define levels of ripening, playing an important role in early performance of species $[2,18,19]$. Thus, metabolomics, as a diagnostic tool, provides a powerful means to gain a better understanding of the physiological responses to environmental stimuli (abiotic and biotic stresses) [20]. For instance, different $\mathrm{N}$ metabolites in seeds between two contrasting quinoa (Chenopodium quinoa) landraces determined a differential nutrition competitiveness, which have developed differential adaptive responses under the low soil-N conditions [19]. In addition, the regulation of metabolic dynamics between primary and secondary metabolites affected the whole-plant performance during various developmental stages, including sink strength, seed formation and fruit ripening [3, 21, 22].

Sacha Inchi (Plukenetia volubilis L.), a tropical fast-growing evergreen liana, is a promising oilseed crop [23, 24]. Being highly plastic responded to environmental factors, seed yield and quality of $P$. volubilis plants largely depend on the suitable agricultural practices $[25,26,27]$. $P$. volubilis plants flower continuously, with peak mature fruits (seeds) occurring in the late-wet season and dry season in southeast China [26, 27]. In the dry season in the seasonal tropical area, female/fruit number and fruit growth of $P$. volubilis plants could be limited by carbohydrate and $\mathrm{N}$ availabilities owing to decrease of photosynthates and reduction in cell turgor under drought. In addition, as a liana species, $P$. volubilis plants formed a flat canopy with abundant leaves; the over-vegetative growth, especially in the wet season, may probably result in decline in flowering and fruit (seed) production. But, until now, no study has explored the mechanisms of $P$. volubilis plants under variable source-sink regulations at physiological and metabolomic levels.

An integrated understanding of physiological traits, growth, and reproductive traits (including metabolites) in response to source-sink regulations is a critical step to increase seed production. In the present work, field experiments were done to elucidate physiological and yield traits in response to defoliation (reduce source) or defloration (reduce sink), which were applied in an intensively cultivated $P$. volubilis plantation in the early-wet season. Specifically, we asked the following questions: (1) Which components of sources and sinks in the plant system and their underlying physiological mechanisms exert the stronger effect over plant growth and/or seed yield? (2) Does defoliation reduce plant growth accompanied by a reduction in $\mathrm{C}$ and/or $\mathrm{N}$ reserves? and what are the 
differences between $\mathrm{C}$ and $\mathrm{N}$ reserves in response to resource-sink regulations? (3) What are metabolomic adjustments in fruitlets in response to source or sink regulation?

\section{Results}

\section{Leaf traits}

Except for the photosynthetic rate $\left(P_{\mathrm{n}}\right)$ and stomatal conductance $\left(\mathrm{g}_{\mathrm{s}}\right)$, there were significant season $\times$ treatment interactions for the measured leaf physiological traits in $P$. volubilis plants (Fig. 1A-F), implying that the responsiveness to defoliation or defloration differed among seasons. For example, defoliation led to a significant increase in leaf $\mathrm{N}$ content in the middle-wet season (August), but had no effects in the later seasons (Fig. 1C).

At the leaf level, $P_{\mathrm{n}}, \mathrm{g}_{\mathrm{s}}, \mathrm{N}$ content and photosynthetic $\mathrm{N}$-use efficiency (PNUE) were highest and lowest in the middle-wet season and the dry season (April), respectively; but the instantaneous water-use efficiency (WUEi) was highest in the dry season across all treatments (Fig. 1). Except for $P_{\mathrm{n}}$ and gs, defoliation or defloration treatment significantly affected the measured leaf traits. Compared with control, defoliation did not affect $P_{\mathrm{n}}$ and $g_{\mathrm{s}}$ in each season, but generally increased $\mathrm{N}$ content and WUEi across all seasons (Fig. 1C, D). In contrast, except for a slightly higher leaf $\mathrm{N}$ content, defloration had no significant effects on other variables compared with control. With the lowest value in the dry season, SLA did not change significantly between different source-sink regulations (Fig. 1F).

\section{Carbohydrates and $\mathrm{N}$ in branches}

The highest and lowest N and NSC contents occurred in the middle-wet and dry season, respectively (Fig. 2A, D). In response to defoliation, although a loss of nutrition reserves (e.g., $\mathrm{N}$ and $\mathrm{P}$ ) in leaves occurred, $\mathrm{N}$ contents in branches increased (Fig. 2A). Relative with sugar, starch content had lower plasticity in response to different treatments and seasonal variation (Fig. 2B, C). NSC contents, especially sugar, sharply decreased after defoliation applied ca. three weeks (August), but were fully recovered in the late-wet season (October) and were maintained in the dry season. In contrast, defloration caused a higher NSC content than the control only in the the middle-wet season (Fig. 2D).

\section{Reproductive traits and plant growth}

Both season and treatment significantly affected the percentage of fruit set (Fig. 3A, B). Fruit set in the latter stage was lower than that in the former stage $(F=0.37, P<0.05)$. Compared with control, defoliation increased, but defloration reduced the percentage of fruit set, especially in the earlier stage (Fig. $3 \mathrm{~A}$, $\mathrm{B})$.

As a recurrent woody plant that blooms and fruits continuously, fruit (seed) maturation of $P$. volubilis plants showed a marked yearly rhythm, with peak values occurring in the dry season (from December to April) (Fig. 4A). Significant season $\times$ treatment interactions affected seed yield, suggesting that seed yield responded to defoliation or defloration differed between different harvested dates. Neither defoliation nor defloration affected the first peak harvest time (i.e., December), but the yield of the peak matured fruits harvested in other dates differed significantly between the different treatments (Fig. 4A). For instance, at time of the second harvest, seed yield in the deflorated plants was much higher than that in the defoliated plants. Across over a growing season, the highest mature fruits were obtained at the second and the third harvested date, respectively, in the deflorated and the defoliated plants. But seed size within each harvested date did not differ significantly between three treatments (Fig. 4B). Defloration slightly increased (7.4\%), whereas defoliation significantly decreased the total seed yield (Fig. 5A), whereas the mean seed size throughout the growing season did not differ between three treatments (Fig. 5B). In addition, defoliation, but not defloration, significantly reduced the stem diameter (plant growth) measured at the end of the experiment (Fig. 5C).

To obtain a better understanding of the potential physiological responses of the fruit abortion and development of $P$. volubilis in response to source-sink manipulations, we also analyzed the metabolites in fruitlets after 24 days of defoliation and defloration applied. Both principal component analysis (PCA) and orthogonal projections to latent structures-discriminant (OPLS-DA) analyses showed that all samples were fall in the $95 \%$ Hotelling's T-squared ellipse, and a significant differentiation occurred in the samples between defoliated and deflorated groups (Fig. S2), indicating that source or sink regulation had a substantial effect on the metabolites in fruitlets. Compared with control, defloration increased the contents of five metabolites (D-glyceric acid, threonic acid, D-talose, succinate semialdehyde, (+)-catechin), but decreased only one (i.e., lyxose) (Table 1). Whereas, defoliation increased the contents of thirteen metabolites (D-talose, mannose, xylose, saccharic acid, succinate semialdehyde, ribonic acid, gamma-lactone, 2-deoxy-D-glucose, glucose, melibiose, 2,4diaminobutyric acid, citraconic acid, gluconic lactone), but decreased the contents of three metabolites (glycerol, L-malic acid and lyxose) (Table 2). Hierarchical clustering showed the associations between samples according to the metabolite profile (Fig. 6A, B). The samples that obtained from each treatment were clustered together. In the defloration treatment, only one metabolite (i.e., lyxose) was separated from the others (Fig. $6 \mathrm{~A}$ ). Whereas, in the defoliation treatment, three metabolites (i.e., glycerol, L-malic acid, and lyxose) were grouped in a different cluster (Fig. 6B). Analysis of Kyoto Encyclopedia of Genes and Genomes (KEGG) indicated that defloration affected the biosynthesis of secondary metabolites, including glycerate and catechin (Table 3); while defoliation affected the biosynthesis of secondary metabolites (glucose, malate, and D-glucono-1,5-lactone), galactose metabolism and ABC transporters (glucose, glycerol, mannose, and melibiose), carbon metabolism (malate and D-glucono-1,5-lactone), amino sugar and nucleotide sugar metabolism (glucose and mannose), and pentose phosphate pathway (glucose and D-glucono-1,5-lactone) (Table 4). Furthermore, KEGG pathway analysis indicated that defoliation affected the galactose metabolism, starch and sucrose metabolism, citrate cycle (TCA cycle), pyruvate metabolism, glyoxylate and dicarboxylate metabolism; whereas, we did not find the significant enriched KEGG pathway in the defloration group (Table 5, Fig. 7). Support this assumption, the KEGG pathway analysis indicated that defoliation downregulated the TCA cycle, lipid metabolism, and carbohydrate metabolism in fruitlets (Fig. 8).

\section{Discussion}

\section{Source-sink manipulations did not greatly regulate leaf photosynthesis and morphology}

Page $3 / 18$ 
As expected, with the highest values in the middle-wet season, the seasonal patterns of $P_{\mathrm{n}}$ and $g_{\mathrm{s}}$ in $P$. volubilis plants are consistent with our previous results $[27,28]$. At the leaf level, we did not find evidence that photosynthetic regulation compensated for leaf or fruit loss in the defoliated or deflorated plants, respectively (Fig. 1A). A lack of photosynthetic upregulation and reduced leaf area in the defoliated plants were also reported in black oak trees (Quercus velutina Lam.) [29]. The physiological mechanism that drives the change in $P_{\mathrm{n}}$ following defoliation appears to vary widely between species [14, 30, 31]. Although leaf $\mathrm{N}$ content increased by defoliation, the stable $P_{\mathrm{n}}$ was probably due to the changes in within-cell partitioning of $\mathrm{N}$ within the leaf to decrease Rubisco levels (thus lower PNUE; Fig. 1E) [28, 32]. At the whole-plant level, defoliation can reduce the source:sink ratio for photosynthethate and increase the inhibition on $P_{\mathrm{n}}$ through carbohydrate feedback. Moreover, low soil nutrient availability may restrict the potential for compensatory photosynthesis and growth after defoliation [13]. But this does not seem to be the case in our study, as all plants were sufficiently supplied with fertilizer to avoid growth limitation by soil nutrients. Alternatively, the defoliated plants were less water-stress than those of control plants, which is indicated by higher leaf WUEi values (Fig. 1D, but [6]), largely because of a reduced transition surface. In a young Eucalyptus nitens plantation, the aboveground biomass production per unit transpiration (i.e., stand water-use efficiency) was also increased by shoot pruning [33]. No significant variations in photosynthetic rate in the deflorated plants were found compared with control, suggesting that the sink effect was moderate in 2.5-year-old $P$. volubilis plants bearing approximately hundred fruits.

Across all seasons, the lowest SLA found in the dry season supported the consumption that SLA in leaves that develop under water-deficit conditions was generally lower than those develop under wet conditions [32]. Whereas SLA did not change greatly between different source or sink manipulations (Fig. 1F). It was found that severe fruit pruning did not change leaf morphology (leaf size and area) in oil palm (Elaeis guineensis) [4]. Therefore, a relatively stable SLA of $P$. volubilis plant in response to disturbance is important to maintain leaf structural function and adapt to drought $[25,27]$.

\section{And N Differently Responded To Source-sink Manipulations}

Carbohydrates stored in woody tissues of perennial plants are essential for a sustainable crop production because of their role in nutrient (mainly $\mathrm{N}$ ) uptake and assimilation, leaf area formation, and inflorescence induction, particularly under stress situations [2]. Since $P$. volubilis plants have extremely small root biomass fraction (ca. 6\%) and store only very little NSC in roots [27, 34], vegetative aboveground tissues have to assume these functions. NSC contents across plant tissues on diurnal and seasonal scales are generally assumed to be indicative of the $\mathrm{C}$ balance, i.e., the difference between $\mathrm{C}$ supply (photosynthesis) and demand (export and growth) $[5,8,31]$. The highest and lowest NSC contents occurred in the middle-wet season and in the dry season, respectively (Fig. 2D), reflecting the phenomenon of 'refill' and 'carbon depletion' during the wet and dry season, respectively. Water stress in the dry season can cause substantial inhibition of photosynthesis and may have necessitated a decrease in carbohydrate mobilization from storage tissues [27, 35]. Whereas in a pot experiment with four grapevine varieties, it was found that an increase rather than a decrease in carbohydrate levels in wood tissues under prolonged drought because of the decreased demand of aboveground growth [36].

NSC contents (especially sugar) were sharply reduced within a short period (three weeks) after defoliation applied in the early-wet season, but were completely recovered in the late-wet season and were maintained in the dry season (Fig. 2B, D). Our findings are consistent with the consumption that fast-growing species (e.g., P. volubilis), typically having low leaf construction costs and more flexible growth strategies, respond rapidly to defoliation, through changes in carbohydrate contents [37]. Defoliated plants reduced NSC contents, although temporally, either by reducing the photosynthetic apparatus and/or by triggering new foliage growth, but not by the compensatory photosynthesis observed (Fig. 1A). On the other hand, defloration increased available resources through sink limitation, as indicated by the continuous increase in NSC reserves (Fig. 2D). This was probably the cause of the less resource competitions between the remaining fruits and also between vegetative and reproductive tissues. Thus, carbohydrate reserves in vegetative tissues of $P$. volubilis plants served to buffer sink-source imbalances that may result from temporary reductions in demand for assimilates (e.g., defloration) or shortfalls in carbon assimilation (e.g., defoliation) $[9,10,38]$.

After defoliation, $\mathrm{C}$ and $\mathrm{N}$ limitations are assumed to result in the decreased plant growth and even plant mortality, especially in evergreen species that they have abundant nutrition reserves (e.g., $\mathrm{N}$ and $\mathrm{P}$ ) in leaves year-round [1, 31]. Compared with control, the defoliated $P$. volubilis plants had a temporally reduced NSC contents and lower long-term growth (Fig. 5C). This was consistent with the result of a large-scale manipulative field experiment in a hybrid poplar plantation, where repeated defoliation lead to long-term growth decline but only transient $\mathrm{C}$ storage reduction occurred [38]. On the other hand, defoliation lead to the increased $\mathrm{N}$ contents in both remaining leaves (Fig. 1C) and branches (Fig. 3A). This was probably resulted from the facts that the incensement of the internal $\mathrm{N}$ availability contributed to the initiation of new axes and the functional biomass partition between woody tissues and/or the enhanced $\mathrm{N}$ uptake from soils increased $\mathrm{N}$ contents in plant tissues $[2,7,38,39]$. Thus, $\mathrm{C}$ limitation, but not $\mathrm{N}$ remobilization, is a source-driven growth process in $P$. volubilis plants [cf. 1]. But for a winter-deciduous temperate adult tree (Nothofagus pumilio), the greatly reduced plant growth induced by extreme defoliation was due to growth limitations (i.e., preventative $\mathrm{C}$ allocation to storage), not to insufficient $\mathrm{C}$ or $\mathrm{N}$ availability [15]. A more integrated understanding of the possible shifts in $\mathrm{C}$ and/or $\mathrm{N}$ limitation on growth and the yield that occur during the lifetime of $P$. volubilis plants, is required.

\section{Source-sink Manipulations Differently Regulated Reproductive Traits}

After defoliation, either the advanced or delayed budburst was found in some temperate deciduous fruit trees (e.g., peach, [40]; walnut, [41]), because of the dose-dependent response of the supply of sugars (especially sucrose) involved in budburst processes. For the recurrent woody plants that bloom and fruit continuously in tropical areas, flowering and fruit maturation date show a marked yearly rhythm but the control of their periodicity is not well understood. Largely determined by temperature and photoperiod in plants without a vernalization requirement within a growing season [32], the phonological development of $P$. volubilis plants, i.e., initial peak mature time, was not affected by source-sink regulations (Fig. 4A), which was contrary to its response to long-term exposure to shade [42]. But the dynamic pattern of the yield in the most peak mature dates differed between different treatments. The highest mature fruits

Page $4 / 18$ 
were harvested earlier in the deflorated plants than the control; the reverse is true in the defoliated plants (Fig. 4A). A decrease in assimilate supply, due to leaf removal, might increase early fruit abortion thus delayed fruit maturation in evergreen trees [43].

Combined with a small fraction of fruit sets (<40\%, Fig. 3; [34]), the well-developed reproductive tissues (i.e., relatively large flower numbers per plant; [25]) indicated that flower initiation did not limit the number of fruits produced. But the fruit retention and development are the limiting factors for the yield of the wind-pollinated $P$. volubilis plants. Fruit (seed) number is a dominant factor for seed yield in $P$. volubilis plants because seed size in each harvested date and throughout the growing season did not differ significantly between three treatments (Fig. 4B; Fig. 5B). Along with our previously studies that fruit (seed) number, rather than seed size, responded greatly to agricultural management practices (e.g., fertilizers, irrigation and plant density; [25, 26, 27]), our results supported that, from an evolutionary perspective, plants would have much less plasticity in seed weight than in seed number [44]. Increased fruit (seed) production following artificial defoliation or herbivory (i.e., overcompensation) has been found in some wild plant species and herb crops (e.g., potatoes), but the potential negative or zero effect of source-reducing on crop yield depends on the studied crop species and plant size, environmental conditions, and the frequency and intensity of defoliation [45]. Fruit development can be supplied with $\mathrm{C}$ imported either from current photoassimilates of neighboring branches or from $\mathrm{C}$ reserves stored in the woody tissues. Defloration slightly increased, whereas defoliation greatly decreased the total seed yield (Fig. 5B). This implied that source-sink regulations affected fruit (seed) yield mainly by decreasing flower bud number and/or inducing fruit abortion, rather than individual fruit growth (size).

The alteration of the whole-plant carbon balance induced by source-sink regulations affect nutrition and carbon reserve in leaves and the reproductive tissues (flowers and fruitlets), leading to abscission [10,43]. In addition, fruit abortion not only depends on the source strength but also on the sink strength of competing tissues $[9,11,46]$. Within a plant system, the smallest and less developed fruitlets generally undergo abortion, as the strongest fruitlets are positively selected against the weakest ones. In our study, defoliation reduced, but defloration increased the percentage of fruit abortion, especially in the earlier reproductive stage (Fig. 3). Thus, high fruit set of $P$. volubilis plants was involved an increased photosynthetic input and thus increased resource limitation (no defoliation), and less sink strength of competing reproductive tissues (deflorated plants). It was also reported that carbohydrate shortage, especially sugar, leads to dramatically accelerated fruitlet abortion in lychee, a recurrent tropical fruit tree [47]. Generally, plants with a larger plant size (stem diameter) had the higher total seed yield across all treatments (Fig. 5C), indicating that the amount of stored resources (i.e., carbohydrate and $\mathrm{N}$ ) from maternal plants mainly determine the seeds (fruits) numbers during the reproductive stage [27, 42]. Compared with control, the reduced amount of current and stored carbohydrates by defoliation during the reproductive stage may restrict the numbers of fruits (fruit load; but see olive tree [12]), especially in the dry season when water was limited [25]. Carbohydrates (especially sugar) play a key role in flower bud formation and their levels can be directly correlated with floral induction in fruit trees [11]. Our results may indicate that fruit retention and thereafter mature fruit number, rather than individual seed development (size), is strongly source limited in P. volubilis plants [c.f. 27]. However, in response to source-sink manipulations applied in the early-wet season, we still cannot know whether the varied mature fruit number (load) is due to a direct effect of fruit set, or an indirect effect caused by changes on the total fruit number per plant, or a complex carbohydrate and hormone signalling crosstalk controlling flower/fruitlet abscission [2].

On the other hand, to promote the understanding of fruit (seed) development and their metabolic regulations in $P$. volubilis plants, we characterized the primary and secondary metabolome in fruitlets after 24 days of source/sink regulation applied. The source or sink regulation had a substantial effect on the metabolites in fruitlets, as a significant differentiation occurred in the samples between defoliated and deflorated groups (Fig. S2). Compared with control, fewer metabolites in fruits showed relatively lower fluctuations in the defoliated plants than in the deflorated plants, especially for the secondary metabolites $($ Table 1, 2). Secondary metabolites are essential in the interactions with the environmental stressors, rather than playing a key role in plant growth [32]. Given that defloration is known to reduce the competition for carbohydrate source and thus promote fruit size and carbohydrate content in several fruit trees including peach [48] and apple [49], it can be expected that the assimilated photosynthetic carbohydrate in the deflorated $P$. volubilis plants might be diverged to growth rather than to secondary metabolite synthesis in fruitlets. Defoliation downregulated the TCA cycle and carbohydrate metabolism in fruitlets (Fig. 8), resulting in carbon starvation and insufficient energy metabolism, thus inhibiting the growth and enhancing fruit abortion [11, 47]. Moreover, at the whole-plant level, regulation of primary metabolism determines the C:N balance and also affects sink strength [3, 21]. The decreased content of malic acid by defoliation may limit the energetic cost for fruit development, as it serves as a crucial intermediate involved in several metabolic pathways, such as TCA cycle, amino acid metabolism and biosynthesis of plant secondary metabolites. Interestingly, compared with control, both defoliation and defloration decreased lyxose content $($ Table 1, 2). Direct regulatory role of this compound is unclear. It was found that xylose is a major component of the pericarp cell walls of tomato fruits [22]; the metabolism of this hemi-cellulose is key for wall loosening linked with cell expansion [50]. Moreover, fruit xylose was connected to leaf trehalose, possibly linking leaf sugar sensing to fruit expansion [22]. On the other hand, the lipid production stage of oilseed development in requires significant demand on carbon sources, such as sugars produced by photosynthesis in the leaves [51]. Defoliation, but not defloration, reduced the content of glycerol (Table 2), a product from lipid metabolism, implying that the reduced lipid accumulation occurred in seeds. Overall, this study indicated potentially important metabolites that are correlated to the potential fruit abortion and fruit development would provide a basis for further study on the process of fruit maturation during various developmental stages.

\section{Conclusions}

To our knowledge, this is the first study to infer the effect of source-sink regulations on the physiological and reproductive traits of a recurrent evergreen woody crop, P. volubilis. Compared with control, although the temporally reduced NSC contents (especially sugar) can be fully recovered, the decreased growth in the defoliated plants was caused by $\mathrm{C}$ limitations, rather than insufficient $\mathrm{N}$ availability. The changed seasonal dynamic pattern of fruit ripening by sourcesink regulations was probably due to the alterations of fruit abortion and crop load (mature fruit number). Carbohydrate reserves, served to buffer sink-source imbalances, may adjust the demand for assimilates or shortfalls in carbon assimilation. Defloration increased, whereas defoliation decreased the total seed yield throughout the growing season, which was determined by the mature fruit number, rather than individual fruit development (size). Source or sink regulation had a substantial influence on the metabolites in fruitlets. Slightly defloration but defoliation is recommended for both the yield and carbohydrate 
and lipid accumulation in fruits in the strong source-limited $P$. volubilis plants. A long-term research work is needed to understand how whole plant physiology are regulated by source-sink relationships under environmental and developmental constraints between seasonal and yearly variations for this recurrent crop, which has a complex phenology and is substantially affected by defoliation [2, 3].

\section{Methods}

\section{Experimental site and plant material}

The experiment was conducted in Xishuangbanna Tropical Botanical Garden $\left(21^{0} 56^{\prime} \mathrm{N}, 101^{0} 15^{\prime} \mathrm{E}, 560 \mathrm{~m}\right.$ asl), Chinese Academy of Sciences. Owing to the southwest monsoon in Xishuangbanna, distinct wet (from May to October) and dry (from November to April) season occurred. The average annual rainfall there is $1,500 \mathrm{~mm}$, ca. $85 \%$ of which falls in the wet season. The average annual temperature is $22.9^{\circ} \mathrm{C}$. The physico-chemical traits in soils of the top layer $(0-$ $20 \mathrm{~cm}$ ) were described in our previous work [27]. Meteorological conditions in the study area during the experimental period are summarized in Fig. S1, which was available as Supplementary Data Online.

Seeds of $P$. volubilis plants were obtained from a commercial company in south America (Namaskar S.A.C. Inc., Lima, Peru). P. volubilis plants flower about six months after seeds were sown. The field experiments were conducted in $P$. volubilis plantations using 2.5-year-old plants, which were cultivated at intra- and inter-row spacing of $2.0 \mathrm{~m}$ and $2.0 \mathrm{~m}$, respectively. A split-plot design with randomized complete blocks was arranged; three replications in a $2 \mathrm{~m} \times 44 \mathrm{~m}$ sized plot were used in each treatment. Compound fertilizer (150 kg per ha) was spread in early June each year, according to our previous agriculture management practice [25]. Due to the non-self-supported adult liana, all $P$. volubilis plants were supported by steel wire to a height of $1.6 \mathrm{~m}$. To avoid edge effects, only the central healthy plants in the plots were selected.

\section{Source-sink manipulations}

A total of 8-10 plants were selected within each plot. The source-sink manipulation took place between June 28 and 2 July 2016 (i.e., in the early-wet season when plants grow fast) and was performed randomly. Prior to defoliating and defoliating, for each plant, the numbers of the canopy mature leaves (net $\mathrm{C}$ sources) and fruitlets (diameter $<1 \mathrm{~cm}$, net $\mathrm{C}$ sink tissues) was counted. In each block, plants were randomly assigned to one of the treatments: defoliation (randomly cutting ca. 10\% canopy mature leaves in each branch per plant), defloration (randomly thinning $10 \%$ fruitlets in each branch per plant), and control (neither defoliation nor defloration). Buds in the defoliated or deflorated plants were unaffected. A total of ten to twelve plants were monitored within each treatment in three selected plots.

\section{Photosynthetic traits and chemical measurements}

Gas exchanges were made in the morning between 9:00 and 11:30 with a Li-Cor LI-6400 system, in August 20 (middle wet season), October 14 (late wet season) in 2016, and April 12 (dry season) in 2017, respectively. Four to six plants were selected per treatment for the photosynthetic measurements in each season; one fully-expanded, mature canopy leaf was measured per plant. The net light-saturated photosynthetic rate $\left(P_{n}\right)$ and stomatal conductance $\left(g_{\mathrm{s}}\right)$ were measured under the light-saturating irradiance and ambient $\mathrm{CO}_{2}$ concentration as described previously [41]. Subsample of leaves was scanned by a desktop scanner, and the image was analysed for leaf area. After photosynthetic measurements, leaves and 1-year-old branches in each season were harvested and were then weight after drying at $70^{\circ} \mathrm{C}$ for $48 \mathrm{~h}$, and was used for the measurement of $\mathrm{N}$ content. Specific leaf area (SLA=leaf area/leaf mass), instantaneous water-use efficiency $\left(\mathrm{WUEi}=P_{n} / \mathrm{gs}\right)$ and photosynthetic $\mathrm{N}$-use efficiency $\left(\mathrm{PNUE}=P_{n} / \mathrm{N}\right)$ were then calculated.

Total $\mathrm{N}$ content of leaf or branch sample was determined using the standard micro-Kjeldahl method. The dried branch tissue was also analysed for NSC, defined as the sum of starch and total soluble sugar, following the enzymatic digest and ultraviolet spectrophotometry methods modified from DuBois et al. (1956) [52]. We focused mainly on carbohydrate content, since a shift in carbohydrate content relative to controls following disturbance is indicative of $\mathrm{C}$ storage being used for regrowth $[25,26]$.

\section{Reproductive characteristics}

Stem diameter of each individual plant at $10 \mathrm{~cm}$ above soil level was measured with a calliper to assess plant growth at the end of April 2017 . A total of 30 female flowers with their stigmata open were randomly tagged in each plot in late Nov. 2016 and Jan. 2017, respectively; formation of fruits was then counted within 3 weeks. The percentage of fruit set was calculated as the number of set fruits divided by the number of female flowers $\times 100$.

Mature fruits were harvested manually and repeatedly five times in each individual plant throughout the fruit maturing period; fruit dry mass per plant was measured at each harvest. At each harvest, subsamples of mature fruits were peeled and seed dry mass (size) was weighted. Seed yield in each harvested date and the total seed yield (per plant) throughout a growing season were then calculated as we descripted previously $[24,26]$.

\section{Metabolite profiling analysis in fruitlets}

For the metabolite profiling analysis in fruitlets after 24 days of defoliation or defloration applied, samples of the canopy fruitlets (diameter=1-1.2 cm) were collected in 9:30-10:30 in the sunny morning and immediately frozen in liquid nitrogen and stored at $-80^{\circ} \mathrm{C}$; six biological replications were used in each treatment. Using an Agilent 7890 gas chromatograph system (Agilent, California, Palo Alto, USA) coupled with a Pegasus HT time-of-flight mass spectrometer, metabolite extractions, derivatization and gas chromatography time-of-flight mass spectrometry (GC-TOF MS) analyses from the fruitlets (100 mg FW) were carried out as previously described by Lisec et al. (2006) [53] with some modifications. The details of the measurements and data analysis were described in Supplementary Text Online. 


\section{Statistical analysis}

Two-way ANOVAs with season (S) and treatment (T) as the main factors were used for the morphological, physiological and reproductive variables. Then a Tukey HSD post-hoc test was applied within each factor. To satisfy the assumptions of ANOVAs, the normality and homogeneity of data were checked; when necessary, $\log _{10^{-}}$or square-root transformation was used. All data were analyzed by SPSS software (version 23.0).

\section{Abbreviations}

$P_{n}$, net light-saturated photosynthetic rate; $\mathrm{g}_{s}$, stomatal conductance; WUEi, instantaneous water-use efficiency; PNUE, photosynthetic N-use efficiency; NSC, nonstructural carbohydrates; TCA, tricarboxylic acid; OPLS-DA, orthogonal projections to latent structures-discriminant; PCA, principal component analysis; KEGG, Kyoto Encyclopedia of Genes and Genomes.

\section{Declarations}

\section{Acknowledgments}

We thank Yang C., Dong X. and Liu Y. for their help with the field work and sample collections.

\section{Authors' contributions}

ZC designed and performed experiments. ZC, TX and JC wrote the paper. All authors have read and approved the manuscript.

\section{Funding}

Design of the study, analysis and interpretation of data (plant growing and phenotyping), as well as writing and publication of this article were supported by the grants (31670686 and 31971697) from the National Natural Science Foundation of China.

\section{Availability of data and materials}

The datasets generated during the current study are available from the first author on reasonable request.

\section{Supplementary data}

Supplementary material related to this article can be found in the online version.

\section{Ethics approval and consent to participate}

Not applicable.

\section{Consent for publication}

Not applicable.

\section{Competing interests}

The authors declare that they have no competing interests.

\section{References}

1. Millard P, Grelet GA. 2010. Nitrogen storage and remobilization by trees: eco-physiological relevance in a changing world. Tree Physiol. 2000;30:10831095.

2. White AC, Rogers A, Rees M, Osborne CP. 2016. How can we make plants grow faster? A source-sink perspective on growth rate. J Exp Bot. 2016;67:3145.

3. Fernie AR, Bachem CWB, Helariutta Y, et al. Synchronization of developmental, molecular and metabolic aspects of source-sink interactions. Nat Plants 2020;6:55-66.

4. Legros S, Mialet-Serra I, Caliman JP, et al. Phenology, growth and physiological adjustments of oil palm (Elaeis guineensis) to sink limitation induced by fruit pruning. Ann Bot. 2009;104:1183-1194.

5. Yu SM, Lo SF, Ho TH. 2015. Source-sink communication: regulated by hormone, nutrient, and stress cross-signaling. Trend Plant Sci. $2015 ; 20: 844-857$.

6. Lavigne MB, Little CH, Major JE. Increasing the sink:source balance enhances photosynthetic rate of 1-year-old balsam fir foliage by increasing allocation of mineral nutrients. Tree Physiol. 2001;21:417-426.

7. Mediene S, Jordan MO, Pagès L, Lebot J, Adamowicz S. The influence of severe shoot pruning on growth, carbon and nitrogen status in young peach trees (Prunus persica). Tree Physiol. 2002;22:1289-1296.

8. Mialet-Serra I, Clement-Vidal A, Roupsard O, Jourdan C, Dingkuhn M. 2008. Whole-plant adjustments in coconut (Cocos nucifera) in response to sinksource imbalance. Tree Physiol. 2008;28:1199-1209. 
9. McFadyen L, Robertson D, Sedgley M, Kristiansen P, Olesen T. Time of pruning affects fruit abscission, stem carbohydrates and yield of macadamia. Funct Plant Biol. 2012;39:481-492.

10. Iglesias DJ, Tadeo FR, Primo-Millo E, Talon M. Fruit set dependence on carbohydrate availability in citrus trees. Tree Physiol. 2003;23:199-204.

11. Ruan YL, Patrick JW, Bouzayen M, Osorio S, Fernie AR. Molecular regulation of seed and fruit set. Trends Plant Sci. 2012;17:656-665.

12. Bustan A, Avni A, Lavee S, et al. Role of carbohydrate reserves in yield production of intensively cultivated oil olive (Olea europaea L.) trees. Tree Physiol. 2011;31:519-530.

13. Pinkard EA, Battaglia M, Mohammed CL. Defoliation and nitrogen effects on photosynthesis and growth of Eucalyptus globulus. Tree Physiol. 2007;7:1053-1063.

14. Eyles A, Pinkard EA, Davies NW, Corkrey R, Churchill K, O'Grady AP, Sands P, Mohammed C. Whole-plant versus leaf-level regulation of photosynthetic responses after partial defoliation in Eucalyptus globulus saplings. J Exp Bot. 2013;64:1625-1636.

15. Piper Fl, Gundale MJ, Fajardo A. Extreme defoliation reduces tree growth but not C and N storage in a winter-deciduous species. Ann Bot. 1025;115:10931103.

16. Pinkard EA, Beadle CL. Regulation of photosynthesis in Eucalyptus nitens (Deane and Maiden) Maiden following green pruning. Trees 1998;12:366-376.

17. Eyles A, Smith D, Pinkard EA, et al. Photosynthetic responses of field-grown Pinus radiata trees to artificial and aphid-induced defoliation. Tree Physiol. 2011;31:592-603.

18. Jing S, Malladi A. Higher growth of the apple (Malus $x$ domestica Borkh.) fruit cortex is supported by resource intensive metabolism during early development. BMC Plant Biol. 2020;20:75.

19. Pinto-Irish K, Coba de la Pena T, Ostria-Gallardo E, et al. Seed characterization and early nitrogen metabolism performance of seedlings from Altiplano and coastal ecotypes of Quinoa. BMC Plant Biol. 2020;20:343.

20. Johnson $\mathrm{CH}$, Ivanisevic J, Siuzdak G. Metabolomics: beyond biomarkers and towards mechanisms. Nat Rev Mol Cell Biol. 2016;17:451-459. \

21. Gotz KP, Staroske N, Radchuk R, et al. Uptake and allocation of carbon and nitrogen in Vicia narbonensis plants with increased seed sink strength achieved by seed-specific expression of an amino acid permease. J Exp Bot. 2007;58:3183-3195.

22. Bénard C, Bernillon S, Biais B, et al. 2015. Metabolomic profiling in tomato reveals diel compositional changes in fruit affected by source-sink relationships. J Exp Bot. 2015;66:3391-3404.

23. Cai ZQ, Jiao DY, Tang XS, Dao XS, Cai CT. Leaf photosynthesis, growth and seed chemicals of Sacha Inchi (Plukenetia volubilis) plants cultivated along an altitude gradient. Crop Sci. 2012;52:1859-1867.

24. Kodahl N. Sacha inchi (Plukenetia volubilis L.)-from lost crop of the Incas to part of the solution to global challenges? Planta 2020;251:80.

25. Jiao DY, Xiang MH, Li WG, Cai ZQ. Dry-season irrigation and fertilisation affect the growth reproduction, and seed traits of Plukenetia volubilis L. plants in a tropical region. J Hort Sci Biotech. 2012;87:311-316.

26. Yang C, Jiao DY, Geng YJ, Cai CT, Cai ZQ. Planting density and fertilisation affect the seed and oil yields in Plukenetia volubilis L. plants independently. J Hort Sci Biotech. 2014; 89:201-207.

27. Geng YJ, Chen L, Yang C, Jiao DY, Zhang YH, Cai ZQ. Dry-season deficit irrigation increases agricultural water use efficiency at the expense of yield and agronomic nutrient use efficiency of Sacha Inchi plants in a tropical humid monsoon area. Ind Crops Prod. 2017;109:570-578.

28. Cai ZQ, Chen YJ, Bongers F. Seasonal changes in photosynthesis and growth of Zizyphus attopensis seedlings in three contrasting microhabitats in the tropical seasonal rain forest. Tree Physiol. 2007;27:827-836.

29. Wiley E, Huepenbecker S, Casper BB, Helliker BR. The effects of defoliation on carbon allocation: can carbon limitation reduce growth in favour of storage? Tree Physiol. 2013;33:1216-1228.

30. Pinkard EA, Eyles A, O'Grady AP. Are gas exchange responses to resource limitation and defoliation linked to source:sink relationships? Plant Cell Environ. 2011;34:1652-1665.

31. Piper Fl, Fajardo A. Foliar habit, tolerance to defoliation and their link to carbon and nitrogen storage. J. Ecol. 2014;102:1101-1111.

32. Lambers H, Oliveira RS. Plant Physiological Ecology. Third Edition. 2019. Springer, New York.

33. Forrester DI, Collopy JJ, Beadle CL, et al. 2013. Effect of thinning, pruning and nitrogen fertiliser application on transpiration, photosynthesis and wateruse efficiency in a young Eucalyptus nitens plantation. For Ecol Manage. 2013;288:21-30.

34. Yang C, Jiao DY, Cai ZQ, Gong HD, Li GY. Vegetative and reproductive growth and yield of Plukenetia volubilis plants in responses to foliar application of plant growth regulators. HortScience 2016;51:1020-1025.

35. Candolfi-Vasconcelos M, Candolfi M, Koblet W. Retranslocation of carbon reserves from the woody storage tissues into the fruit as a response to defoliation stress during the ripening period in Vitis vinifera L. Planta 1994;92:567-573.

36. Rühl EH, Alleweldt G. Effect of water stress on carbohydrate accumulation in root and stem of four different grapevine varieties. Wein-Wissenschaft 1990;45:156-159.

37. Atkinson RRL, Burrell MM, Rose KE, Osborne CP, Rees M. The dynamics of recovery and growth: how defoliation affects stored resources. Proc R Soc B. 2014;281:20133355.

38. Kosola KR, Dickmann DI, Paul EA, Parry D. Repeated insect defoliation effects on growth, nitrogen acquisition, carbohydrates, and root demography of poplars. Oecologia 2001;129:65-74.

39. Bhadra S, Cai ZQ. Ontogenetic shifts in resource allocation and potential defense syndromes of a tropical medicinal treelet. Ind Crops Prod. 2019;138: 111450. 
40. Maurel K, Leite GB, Bonhomme M, et al. Trophic control of bud break in peach (Prunus persica) trees: a possible role of hexoses. Tree Physiol. 2004;24:579-588.

41. Decourteix M, Alves G, Bonhomme M, et al. Sucrose (JrSUT1) and hexose (JrHT1 and JrHT2) transporters in walnut xylem parenchyma cells: their potential role in early events of growth resumption. Tree Physiol. 2008;28:215-224.

42. Cai ZQ. Shade delayed flowering and decreased photosynthesis: growth and yield of Sacha Inchi (Plukenetia volubilis) plants. Ind. Crops Prod. 2011;34: 1235-1237.

43. Gómez-Cadenas A, Mehouachi J, Tadeo FR, Primo-Millo E, Talon M. Hormonal regulation of fruitlet abscission induced by carbohydrate shortage in citrus. Planta 2000;210:636-643.

44. Sadras VO. Evolutionary aspects of the trade-off between seed size and number in crops. Field Crops Res. 2007;100:125-138.

45. Poveda K, Diaz MF, Ramirez A. Can overcompensation increase crop production? Ecology 2018;99:270-280.

46. Oury V, Caldeira CF, Prodhomme D, et al. Is change in ovary carbon status a cause or a consequence of maize ovary abortion in water deficit during flowering? Plant Physiol. 2016;171:997-1008.

47. Wang HC, Lai B, Huang XM. Litchi Fruit Set, Development, and Maturation. In: Kumar M, Kumar V, Prasad R, Varma A. (eds) The Lychee Biotechnology. Springer, Singapore. 2017.

48. Morandi B, Grappadelli LC, Rieger M, Bianco RL. Carbohydrate availability affects growth and metabolism in peach fruit. Physiol Plant. 2008;133:229241.

49. Link H. Significance of flower and fruit thinning on fruit quality. Plant Growth Regula. 2000;31:17-26.

50. Itai A, Ishihara K, Bewley JD. Characterization of expression, and cloning, of $\beta$-D-xylosidase and a-L-arabinofuranosidase in developing and ripening tomato (Lycopersicon esculentum Mill.) fruit. J Exp Bot. 2003;54:2615-2622.

51. Voelker T, Kinney AT. Variations in the biosynthesis of seed-storage lipids. Ann Rev Plant Physiol Plant Mol Biol. 2001;52:335-361.

52. DuBois M, Gilles KA, Hamilton JK, Rebers PA, Smith F. Colorimetric method for determination of sugars and related substances. Anal Chem. 1956;28:350356.

53. Lisec J, Schauer N, Kopka J, Willmitzer L, Fernie AR. Gas chromatography mass spectrometry-based metabolite profiling in plants. Nat Protoc. 2006;1:387-396.

\section{Tables}

Table 1

Differential metabolite contents in fruitlets between the control and the deflorated group.

\begin{tabular}{|c|c|c|c|c|c|c|c|c|c|c|c|}
\hline Peak & Similarity & R.T. & Count & Mass & MEAN H & $\begin{array}{l}\text { MEAN } \\
\text { CK }\end{array}$ & VIP & P-VALUE & Q-VALUE & $\begin{array}{l}\text { FOLD } \\
\text { CHANGE }\end{array}$ & $\begin{array}{l}\text { LOG_FOLD } \\
\text { CHANGE }\end{array}$ \\
\hline D-Glyceric acid & 824 & $12.6638,0$ & 17 & 189 & 0.401823 & 0.223858 & 2.149468 & 0.049167 & 0.727878 & 1.794990 & 0.8439755 \\
\hline D-Talose 1 & 795 & $18.7309,0$ & 13 & 400 & 0.010151 & 0.001141 & 2.565858 & 0.021771 & 0.727878 & 8.900472 & 3.1538819 \\
\hline Threonic acid & 774 & $15.2487,0$ & 17 & 292 & 0.155878 & 0.109859 & 1.593730 & 0.048319 & 0.727878 & 1.418901 & 0.5047740 \\
\hline $\begin{array}{l}\text { succinate } \\
\text { semialdehyde } 1\end{array}$ & 646 & $10.9787,0$ & 14 & 89 & 0.019193 & 0.003556 & 2.039284 & 0.002755 & 0.727878 & 5.396574 & 2.432044 \\
\hline Lyxose 1 & 631 & $16.3242,0$ & 6 & 307 & 0.000715 & 0.004001 & 2.662419 & 0.013554 & 0.727878 & 0.178766 & -2.4838523 \\
\hline$(+)$-catechin & 356 & $27.6272,0$ & 7 & 369 & 0.001036 & $\begin{array}{l}3.4742 \mathrm{E}- \\
09\end{array}$ & 2.279293 & 0.042309 & 0.727878 & 298172.8 & 18.185789 \\
\hline
\end{tabular}


Table 2

Differential metabolite contents in fruitlets between the control and the defoliated group.

\begin{tabular}{|c|c|c|c|c|c|c|c|c|c|c|c|}
\hline Peak & Similarity & R.T. & Count & Mass & MEAN Y & $\begin{array}{l}\text { MEAN } \\
\text { CK }\end{array}$ & VIP & P-VALUE & Q-VALUE & $\begin{array}{l}\text { FOLD } \\
\text { CHANGE }\end{array}$ & $\begin{array}{l}\text { LOG_FOLD } \\
\text { CHANGE }\end{array}$ \\
\hline glycerol & 834 & $11.9581,0$ & 17 & 205 & 0.216576 & 0.301440 & 1.657182 & 0.042461 & 0.430477 & 0.718473 & -0.476994 \\
\hline glucose 2 & 808 & $18.9806,0$ & 17 & 205 & 2.37325 & 1.651711 & 2.317185 & 0.000408 & 0.085609 & 1.436844 & 0.522903 \\
\hline D-Talose 1 & 795 & $18.7309,0$ & 13 & 400 & 0.010801 & 0.001141 & 2.174023 & 0.001439 & 0.120522 & 9.470816 & 3.243489 \\
\hline mannose 2 & 793 & $18.8215,0$ & 9 & 69 & 0.066114 & 0.014789 & 1.649186 & 0.033848 & 0.411916 & 4.470335 & 2.160383 \\
\hline L-Malic acid & 770 & $14.5738,0$ & 15 & 233 & 0.750475 & 1.840440 & 1.194873 & 0.011054 & 0.296846 & 0.407770 & -1.294174 \\
\hline xylose 2 & 731 & $16.2726,0$ & 14 & 307 & 0.011179 & 0.005439 & 2.104359 & 0.005713 & 0.243256 & 2.05542 & 1.039436 \\
\hline Saccharic acid & 713 & $19.7989,0$ & 16 & 333 & 0.032370 & 0.012739 & 1.11860 & 0.006400 & 0.252564 & 2.541020 & 1.34541 \\
\hline $\begin{array}{l}\text { succinate } \\
\text { semialdehyde } \\
1\end{array}$ & 646 & $10.9787,0$ & 14 & 89 & 0.014395 & 0.003556 & 1.846162 & 0.001179 & 0.112956 & 4.047604 & 2.017068 \\
\hline Lyxose 1 & 631 & $16.3242,0$ & 6 & 307 & $\begin{array}{l}3.2168 \mathrm{E}- \\
09\end{array}$ & 0.004001 & 2.621495 & 0.007627 & 0.266172 & 8.0399E-07 & -20.246319 \\
\hline $\begin{array}{l}\text { Ribonic acid, } \\
\text { gamma- } \\
\text { lactone }\end{array}$ & 545 & $16.7769,0$ & 17 & 220 & 0.014783 & 0.007332 & 2.119316 & 0.006766 & 0.256972 & 2.016307 & 1.011715 \\
\hline $\begin{array}{l}\text { 2-deoxy-D- } \\
\text { glucose } 2\end{array}$ & 539 & $17.762,0$ & 5 & 276 & 0.04742 & $\begin{array}{l}3.4742 \mathrm{E}- \\
09\end{array}$ & 1.912997 & 0.030747 & 0.403271 & 13650449.3 & 23.70245 \\
\hline melibiose 1 & 466 & $27.6702,0$ & 15 & 204 & 0.003359 & 0.001637 & 1.357949 & 0.049263 & 0.441266 & 2.05163 & 1.036769 \\
\hline $\begin{array}{l}2,4- \\
\text { diaminobutyric } \\
\text { acid } 4\end{array}$ & 426 & $16.0886,0$ & 17 & 174 & 0.028417 & 0.012646 & 1.807167 & 0.010068 & 0.289573 & 2.247154 & 1.168099 \\
\hline $\begin{array}{l}\text { Citraconic acid } \\
\text { degr } 1\end{array}$ & 330 & $11.7363,0$ & 17 & 89 & 0.004631 & 0.003053 & 1.422573 & 0.040643 & 0.427094 & 1.516855 & 0.601083 \\
\hline $\begin{array}{l}\text { Gluconic } \\
\text { lactone } 2\end{array}$ & 204 & $18.8577,0$ & 7 & 201 & 0.024234 & $\begin{array}{l}3.4742 \mathrm{E}- \\
09\end{array}$ & 2.007634 & 0.037813 & 0.421305 & 6975510.2 & 22.73387 \\
\hline
\end{tabular}

Table 3

KEGG analysis in fruitlets in the deflorated group.

KEGG Pathway

ath01110 Biosynthesis of secondary metabolites - Arabidopsis thaliana (thale cress) (2) cpd:C00258 D-Glycerate; cpd:C06562 (+)-Catechin

Compound

Table 4

KEGG analysis in fruitlets in the defoliated group.

\section{KEGG Pathway}

ath01100 Metabolic pathways - Arabidopsis thaliana (thale cress) (5)

ath00052 Galactose metabolism - Arabidopsis thaliana (thale cress) (4)

ath02010 ABC transporters - Arabidopsis thaliana (thale cress) (4)

ath01110 Biosynthesis of secondary metabolites - Arabidopsis thaliana (thale cress) (3)

ath01200 Carbon metabolism - Arabidopsis thaliana (thale cress) (2)

ath00520 Amino sugar and nucleotide sugar metabolism -

Arabidopsis thaliana (thale cress) (2)

ath00030 Pentose phosphate pathway - Arabidopsis thaliana (thale cress) (2)

\section{Compound}

cpd:C00031 D-Glucose; cpd:C00116 Glycerol; cpd:C00149 (S)-Malate; cpd:C00159 DMannose; cpd:C00198 D-Glucono-1,5-lactone

cpd:C00031 D-Glucose; cpd:C00116 Glycerol; cpd:C00159 D-Mannose; cpd:C05402 Melibiose

cpd:C00031 D-Glucose; cpd:C00116 Glycerol; cpd:C00159 D-Mannose; cpd:C05402 Melibiose

cpd:C00031 D-Glucose; cpd:C00149 (S)-Malate; cpd:C00198 D-Glucono-1,5-lactone

cpd:C00149 (S)-Malate; cpd:C00198 D-Glucono-1,5-lactone

cpd:C00031 D-Glucose; cpd:C00159 D-Mannose

cpd:C00031 D-Glucose; cpd:C00198 D-Glucono-1,5-lactone 
Table 5

KEGG pathway enrichment analysis in fruitlets in the defoliated group.

\begin{tabular}{|llllllll|}
\hline Pathway & Total & Hits & Raw $\mathbf{p}$ & $-\log (\mathbf{p})$ & Holm adjust & FDR & Impact \\
\hline Galactose metabolism & 26 & 4 & $4.3984 \mathrm{E}-06$ & 12.334 & 0.00038266 & 0.00038266 & 0.08673 \\
\hline Glycerolipid metabolism & 13 & 1 & 0.068704 & 2.678 & 1 & 1 & 0 \\
\hline Fructose and mannose metabolism & 16 & 1 & 0.083971 & 2.4773 & 1 & 1 & 0 \\
\hline Glyoxylate and dicarboxylate metabolism & 17 & 1 & 0.089012 & 2.419 & 1 & 1 & 0.15986 \\
\hline Citrate cycle (TCA cycle) & 20 & 1 & 0.10399 & 2.2634 & 1 & 1 & 0.03272 \\
\hline Carbon fixation in photosynthetic organisms & 21 & 1 & 0.10894 & 2.217 & 1 & 1 & 0 \\
\hline Pyruvate metabolism & 21 & 1 & 0.10894 & 2.217 & 1 & 1 & 0.08561 \\
\hline Starch and sucrose metabolism & 30 & 1 & 0.15241 & 1.8812 & 1 & 1 & 0.06394 \\
\hline Amino sugar and nucleotide sugar metabolism & 41 & 1 & 0.20307 & 1.5942 & 1 & 1 & 0 \\
\hline
\end{tabular}

\section{Figures}
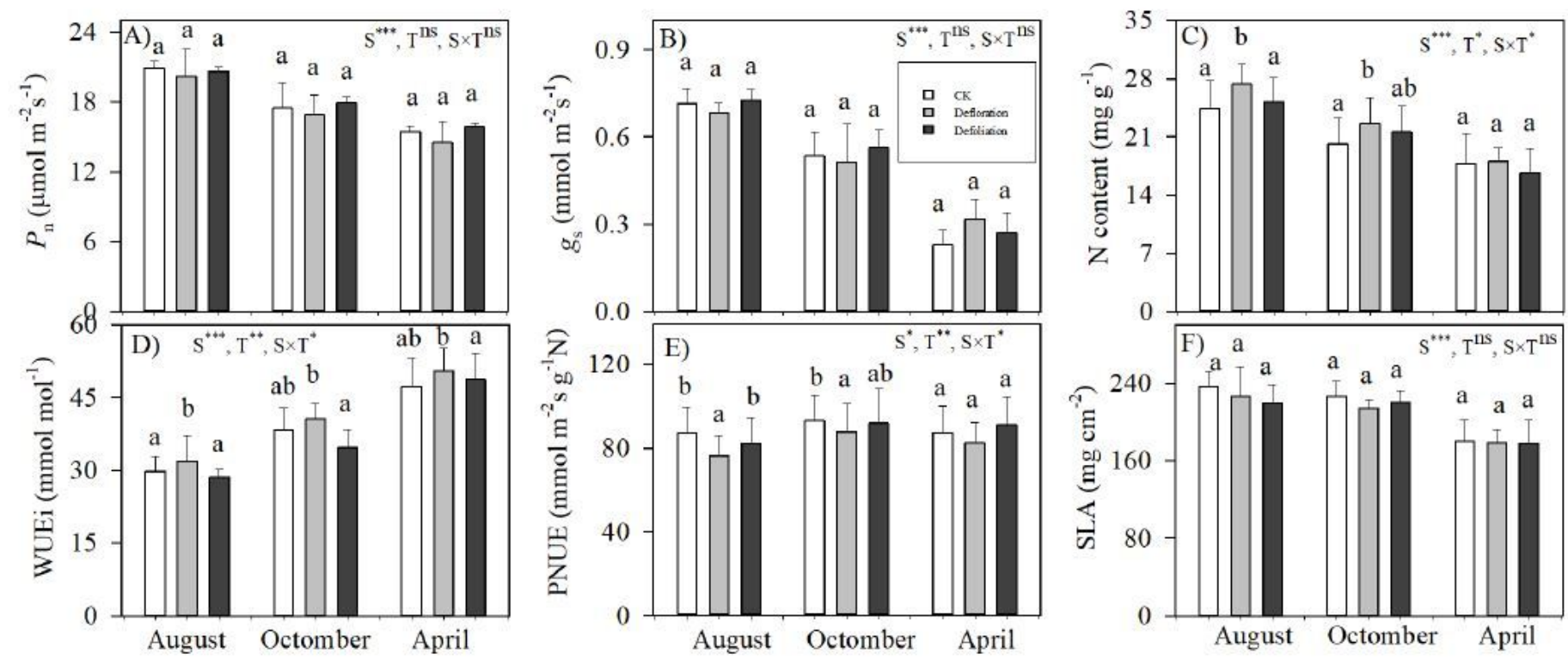

Figure 1

Seasonal variations in leaf morphological and physiological traits variables (means $\pm S D ; n=4-6$ ) of P. volubilis plants in response to defoliation and defloration. Significance levels of ANOVAs testing for the effects of season (S), treatment $(T)$ and their interaction are listed for each variable. The values with different letters within the same season denote significant difference between different treatments at $\mathrm{P}<0.05$ level. CK, control; ns, no significance. ${ }^{*} \mathrm{P}<0.05$; ${ }^{*} \mathrm{P}<0.01 ; * \star \star P<0.001$. SLA, specific leaf area; $\mathrm{Pn}$, net light-saturated photosynthetic rate; gs, stomatal conductance; WUEi, intrinsic water-use efficiency; $P N U E$, photosynthetic N-use efficiency. 

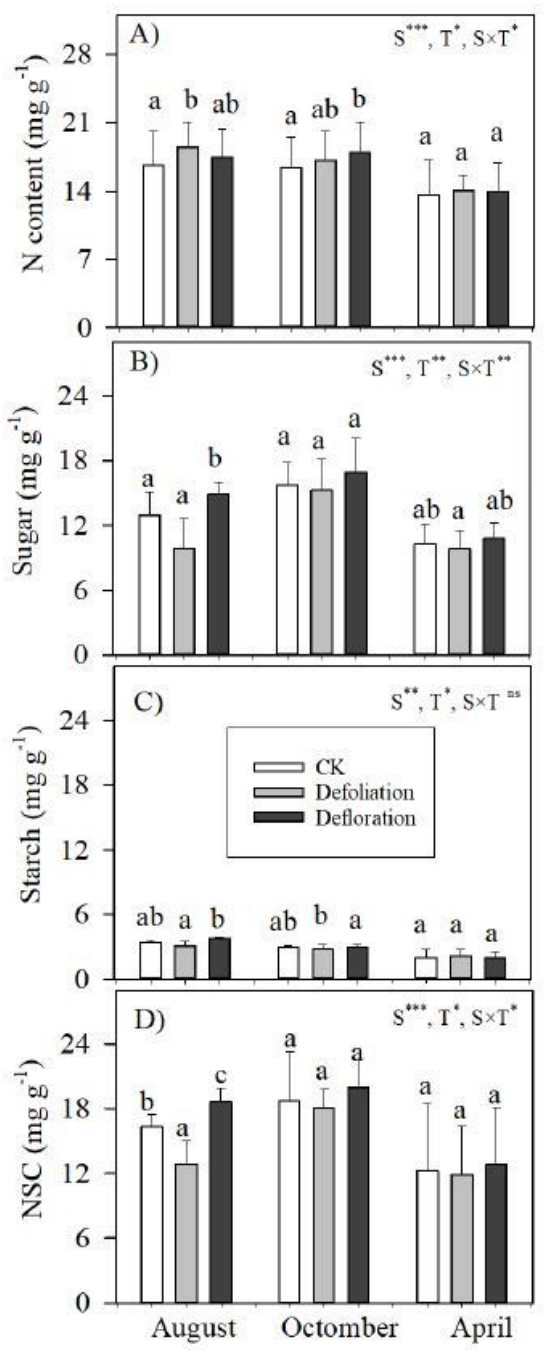

\section{Figure 2}

Seasonal variations of the nitrogen $(\mathrm{N})$ content, soluble sugar and starch content, and total nonstructural carbohydrate content (NSC) in branches (means \pm SD; $n=4-5$ ) of P. volubilis plants in response to defoliation and defloration. Significance levels of ANOVAs testing for the effects of season (S), treatment ( $T$ ) and their interaction are listed for each variable. The values with different letters within the same season denote significant difference between different treatments at $\mathrm{P}<0.05$ level. CK, control; $n s$, no significance. * $\mathrm{P}<0.05 ; * \star \mathrm{P}<0.01 ; * \star * \mathrm{P}<0.001$. 

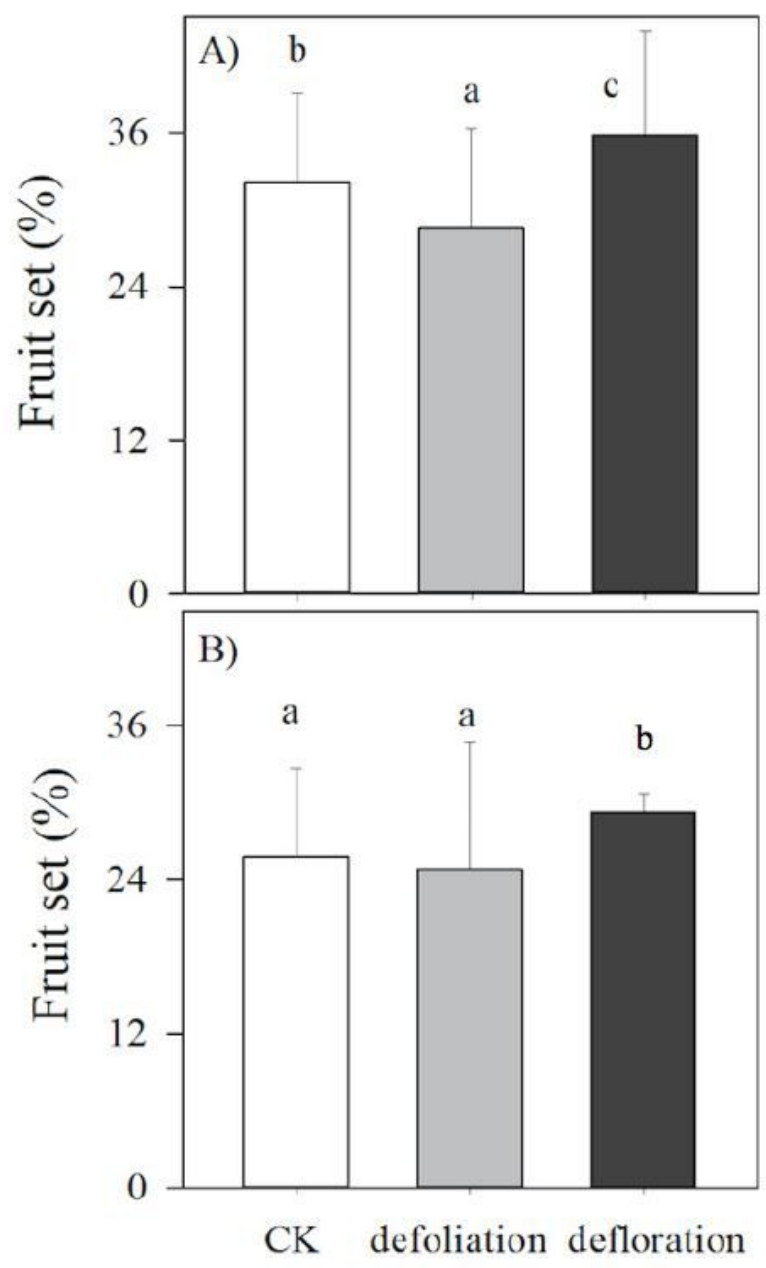

Figure 3

Seasonal variations in the percentage of fruit set (means $\pm S D ; n=10)$ in P. volubilis plants in response to defoliation and defloration. $(A)$ female flowers were tagged in late Nov. 2016. (B) female flowers were tagged in Jan. 2017. The values with different letters within the same season denote significant difference at $\mathrm{P}<0.05$ level. $\mathrm{CK}$, control; ns, no significance. * $\mathrm{P}<0.05 ;{ }^{* \star} \mathrm{P}<0.01 ; * \star \star \mathrm{P}<0.001$. 


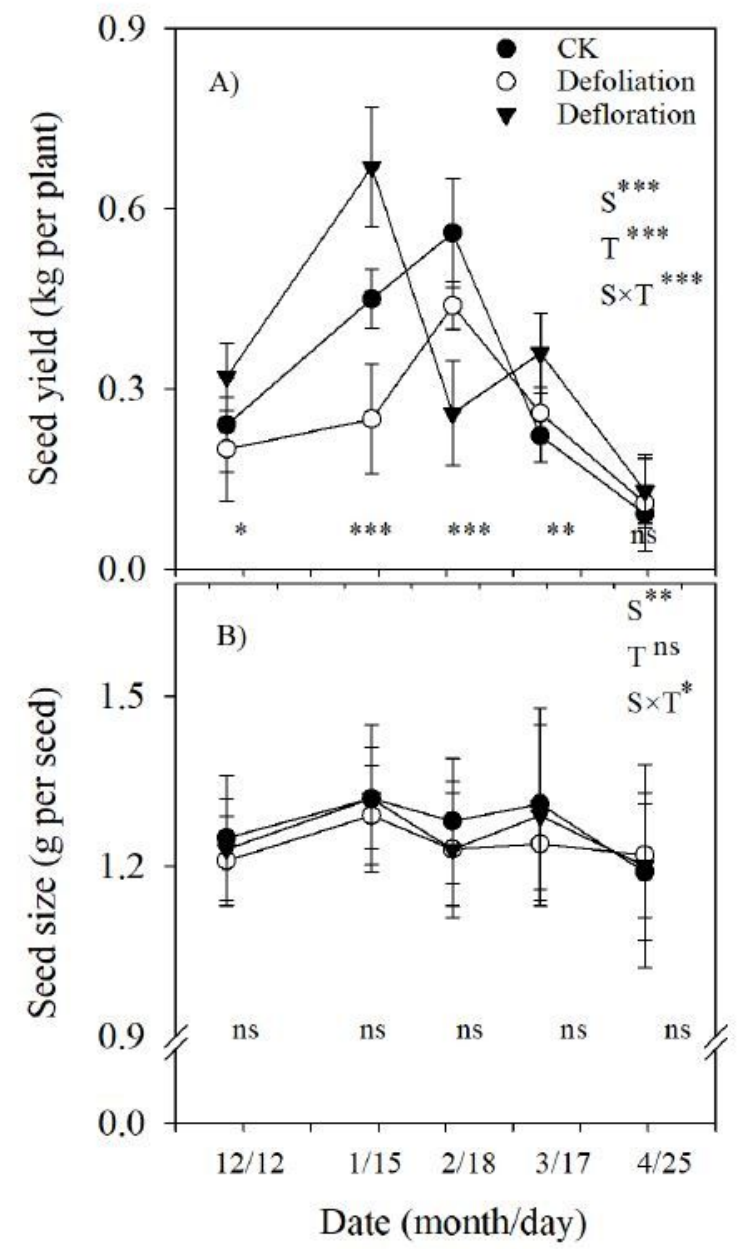

Figure 4

Seasonal dynamics of seed size and seed yield over a growing season of P. volubilis plants in response to defoliation and defloration. Significance levels of ANOVAs testing for the effects of season $(\mathrm{S})$, treatment $(\mathrm{T})$ and their interaction are listed for each variable. CK, control. The asterisk denotes significant difference between different treatments for a given harvested date. ns, no significance. ${ }^{*} P<0.05 ; * * P<0.01 ;{ }^{* \star *} P<0.001$. 


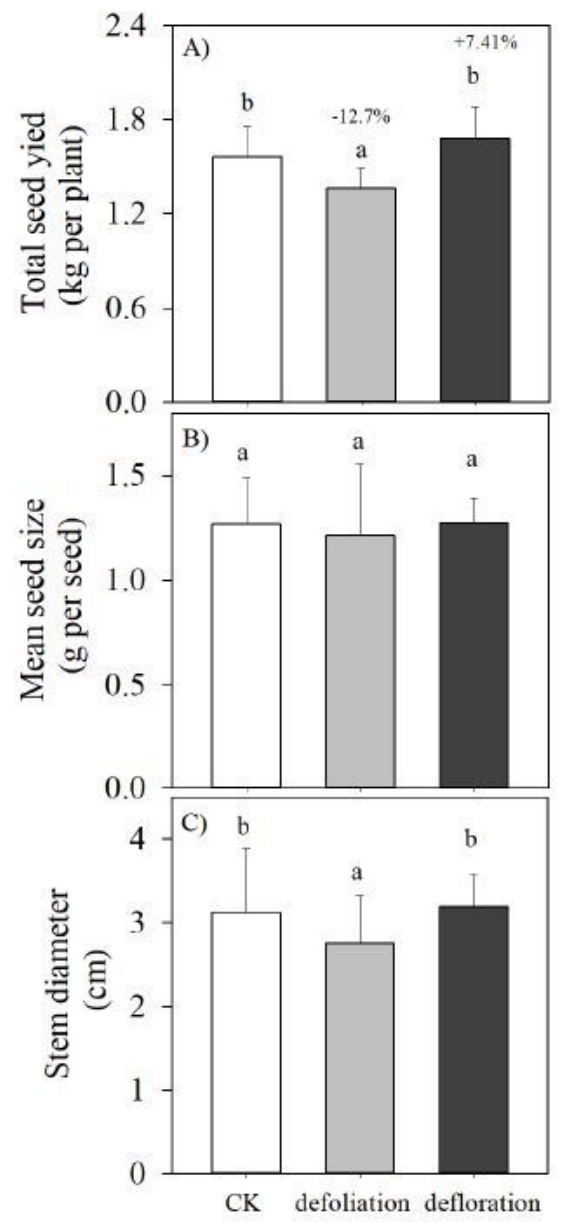

\section{Figure 5}

The mean seed size and total seed yield over a growing season, and growth (stem diameter) of P. volubilis plants in response to defoliation and defloration. The values with different letters denote significant difference between different treatments at $\mathrm{P}<0.05$ level. CK, control. 
A

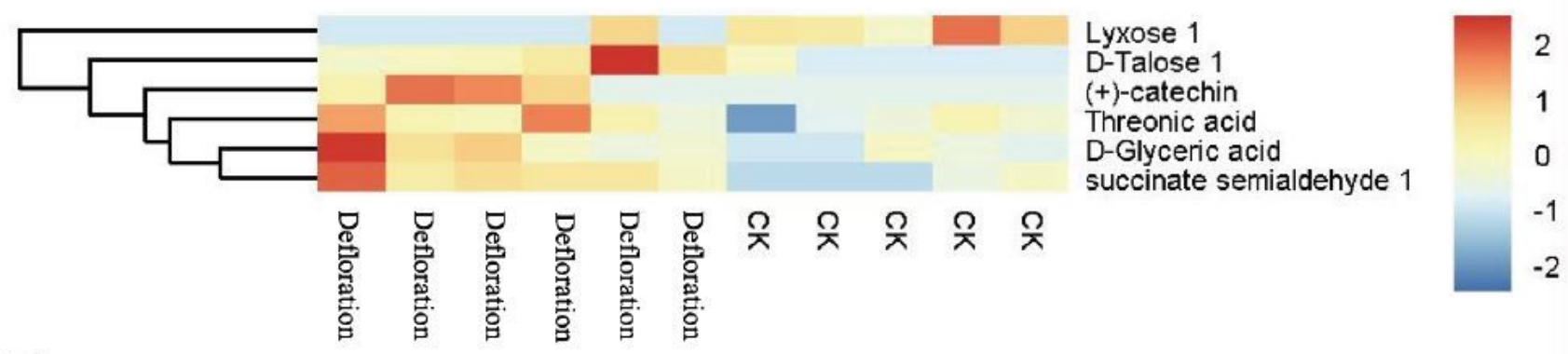

B

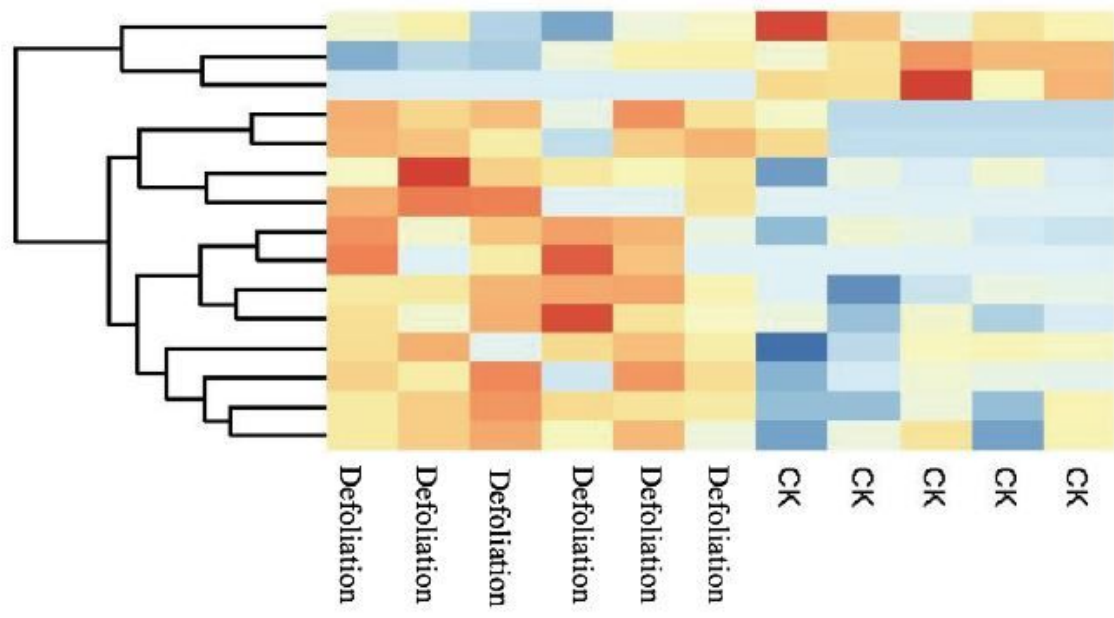

glycerol

L-Malic acid

Lyxose 1

D-Talose 1

mannose 2

Saccharic acid

2-deoxy-D-glucose 2

xylose 2

Gluconic lactone 2

glucose 2

Ribonic acid, gamma-lactone

Citraconic acid degr1

2,4-diaminobutyric acid 4

succinate semialdehyde 1

melibiose 1 


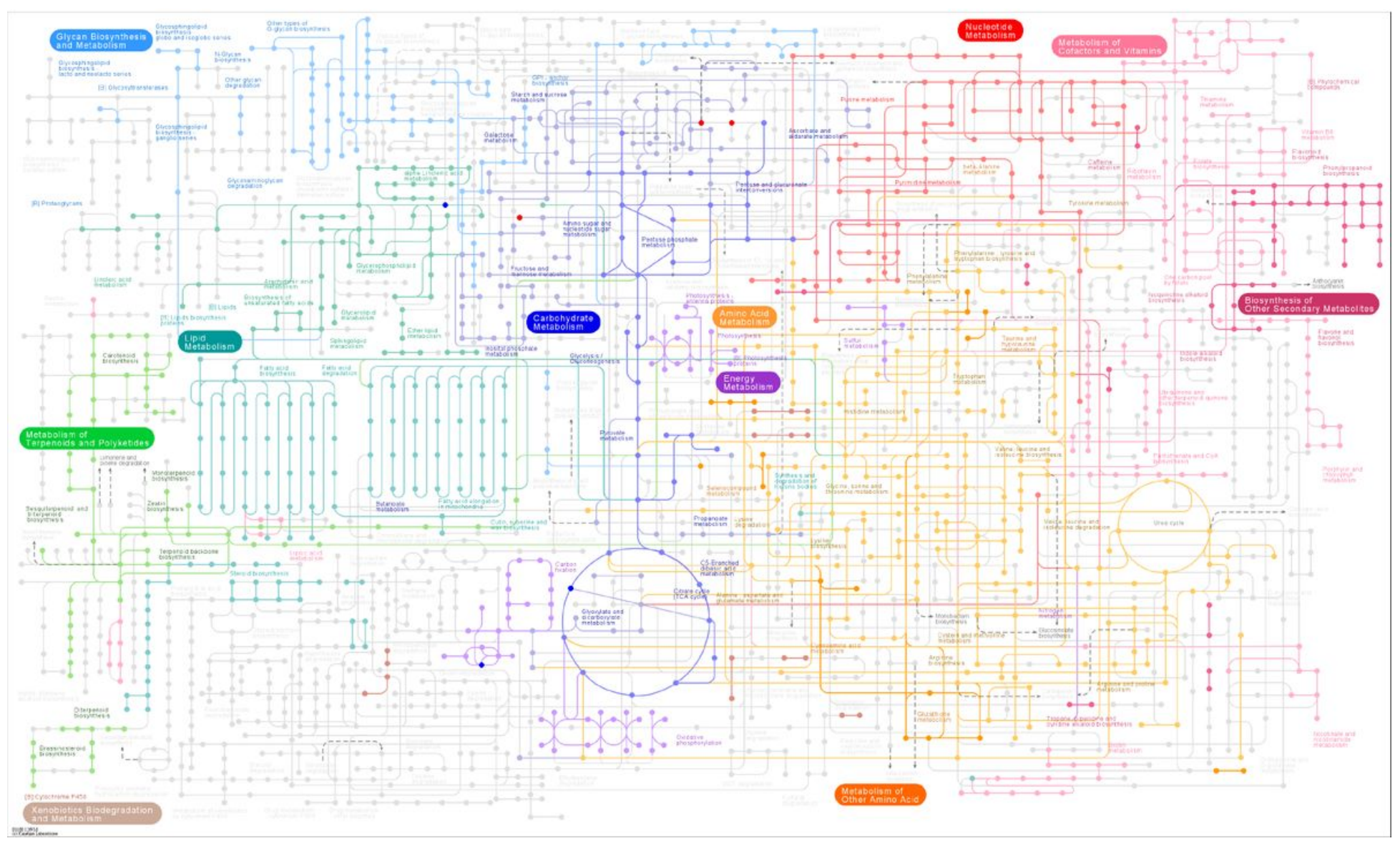

Figure 7

Pathway analysis plot for group defoliation vs. control. 


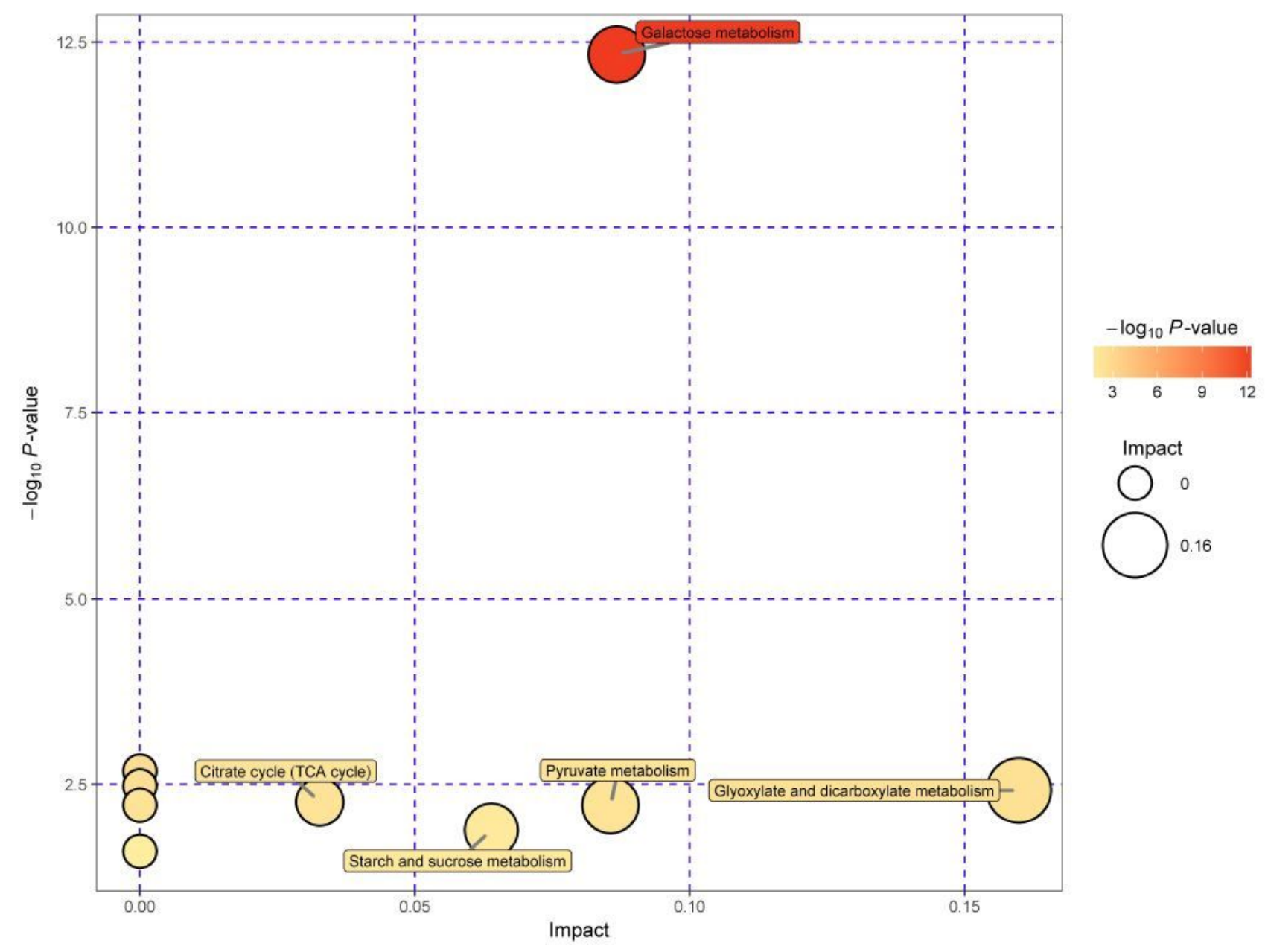

Figure 8

Metabolic pathways with red/blue dots representing the differentially expressed compounds. Warm colors represent upregulation and cold colors represent downregulation.

\section{Supplementary Files}

This is a list of supplementary files associated with this preprint. Click to download.

- Suppl.m.pdf 